\title{
Production, purification and molecular weight determination of the haemolysin of Treponema hyodysenteriae
}

\author{
KAREN A. KENT, RUTH M. LEMCKE and R. J. LYSONS
}

A.F.R.C. Institute for Animal Health, Compton Laboratory, Compton, Newbury, Berkshire RG16 ONN

\begin{abstract}
Summary. The production of haemolysin from Treponema hyodysenteriae was increased by an improved culture method and by repeated incubation of spirochaetes suspended in a buffer containing RNA-core. Ion exchange chromatography on DEAE cellulose followed by gel filtration on Sephadex G100 yielded purified haemolysin free from extraneous protein, as judged by silver-stained polyacrylamide gels. The mol. wt of the purified haemolysin, determined by gel filtration was 19000 , a value similar to that of streptolysin S, but much lower than that previously reported.
\end{abstract}

\section{Introduction}

Treponema hyodysenteriae is a spirochaete that causes swine dysentery (Taylor and Alexander, 1971 ; Harris et al., 1972) and produces $\beta$-haemolysis when grown on blood agar in anaerobic conditions. Production of haemolysin by $T$. hyodysenteriae has been correlated with pathogenicity because nonpathogenic spirochaetes from the porcine intestine are only weakly haemolytic (Hudson et al., 1976; Kinyon et al., 1977; Kinyon and Harris, 1979). However, Hudson et al. (1974) showed that $T$. hyodysenteriae, after 80 passages in vitro, remained haemolytic but was no longer pathogenic for pigs. Thus, the role of the haemolysin in the pathogenesis of swine dysentery has still to be elucidated.

Picard et al. (1979) detected the haemolysin in supernates from cultures of $T$. hyodysenteriae grown in broth containing fetal calf serum, and found that increased amounts were produced when the medium was supplemented with sodium ribonucleate (Na-RNA). Knoop (1981) showed a 400-fold increase in the amount of haemolysin present in culture supernates if yeast ribonucleic acid core (RNA-core) was used instead of Na-RNA. The haemolysin was purified from culture supernates containing serum by Saheb et al. (1980) and Knoop (1981). Saheb et al. (1980) reported that the haemolysin was a high mol. wt polypeptide or protein associated with lipids and nucleotides.

The treponemal haemolysin appears to be similar in several respects to streptolysin $S$, the oxygenstable haemolysin produced by Group-A strepto-

Received 5 April 1988; accepted 12 May 1988. cocci, particularly in its requirement for a carrier molecule which is essential for the production of haemolytic activity from organisms in suspension (Ginsburg, 1970; Bernheimer, 1972). Lemcke and Burrows (1982) reported an improved method for the production of treponemal haemolysin in which spirochaetes were suspended in a defined buffer containing RNA as a carrier molecule. This method was based on the system devised by Bernheimer (1949) for producing a high concentration of streptolysin S.

This report describes the conditions necessary for production of high concentrations of haemolysin from spirochaetes suspended in a buffer containing RNA-core and for its purification. The determination of the mol. wt of the haemolysin is also described.

\section{Materials and methods}

\section{Micro-organisms}

Treponema hyodysenteriae strain P18A was isolated from a pig with experimental swine dysentery induced by strain A1 (Taylor and Alexander, 1971).

\section{Reagents}

All chemicals and electrophoresis-grade reagents, unless otherwise stated, were obtained from BDH Chemicals Ltd, Poole, Dorset. RNA-core Type II C (from Torula yeast), ovalbumin and bovine pancreas RNAase were obtained from Sigma Chemical Company Ltd, Poole, Dorset. Trypticase Soy Broth was from Baltimore Biological Laboratories, Cockeysville, MD; 
yeast extract from Difco Laboratories Ltd, East Molesey, Surrey; rabbit serum from Gibco Ltd, Uxbridge, Middlesex; spectinomycin (Spectam) from Parke, Davis and Co., Pontypool, Gwent (distributors for Abbott Laboratories); and silicone MS antifoam from Hopkin and Williams Ltd, Chadwell Heath, Essex. For filtration, membrane filters were obtained from Millipore (U.K.) Ltd, Harrow, Middlesex and ultrafiltration membranes from Amicon Ltd, Stonehouse, Gloucester. For chromatography, Sephadex was obtained from Pharmacia (Great Britain) Ltd, Hounslow, Middlesex; DEAE cellulose from Whatman Ltd, Parkwood, Kent; and hydroxylapatite (Bio-gel HTP) from Bio-Rad Laboratories, Watford, Herts.

\section{Media and cultivation methods}

Rabbit serum broth (RSB) was prepared by a modification of the method described by Lemcke et al. (1979). The medium consisted of Trypticase Soy Broth (TSB) supplemented with yeast extract $0.2 \% \mathrm{w} / \mathrm{v}$, glucose $0.25 \% \mathrm{w} / \mathrm{v}$, L-cysteine hydrochloride $0.05 \% \mathrm{w} / \mathrm{v}$, resazurin $0.0001 \%$ and Spectam $800 \mu \mathrm{g} / \mathrm{ml}(400 \mu \mathrm{g} / \mathrm{ml}$ soluble spectinomycin). This basal medium was autoclaved, gassed with deoxygenated $\mathrm{N}_{2}$, stored at $4^{\circ} \mathrm{C}$ and used within 7 days of preparation. Immediately beforc use, the basal medium was further supplemented under a stream of deoxygenated $\mathrm{N}_{2}$ with $\mathrm{CO}_{2} 10 \%$ with freshly prepared sodium bicarbonate $0.2 \%$ and rabbit serum $10 \%$. Medium was dispensed in $2-\mathrm{ml}$ volumes in $6 \times \frac{1}{2}$-in tubes or in $50-\mathrm{ml}$ volumes in $20-\mathrm{oz}$ bottles and sealed under $\mathrm{N}_{2}$ with $\mathrm{CO}_{2} 10 \%$.

For culture volumes of $500 \mathrm{ml}$ and $1 \mathrm{~L}$, a modification of the method described by Harris (1980) was adopted employing a 1- or 2-L side-arm flask with a magnetic stirrer (fig. 1). TSB was prepared in the culture vessel and supplemented as above except that cysteine hydrochloride was omitted and $0.1 \mathrm{ml}$ of silicone MS antifoam was included. The medium was autoclaved and then gassed continuously with deoxygenated $\mathrm{N}_{2}$ with $\mathrm{CO}_{2} 10 \%$. When the temperature had dropped to $45-50^{\circ} \mathrm{C}$, rabbit serum $5 \%$, cysteine hydrochloride $0.1 \%$ and sodium bicarbonate $0 \cdot 18 \%$ (the last two freshly prepared) were added. Gassing was continued for a further 15-30 min after which the flask was sealed. Tube and bottle cultures were inoculated with $1 \% \mathrm{v} / \mathrm{v}$ of a $48-\mathrm{h}$ culture of $T$. hyodysenteriae and were incubated at $37^{\circ} \mathrm{C}$ horizontally to maximise the gas-liquid interface. Flasks were inoculated with a $10 \%$ inoculum from a 48 -h bottle culture, stirred continuously during incubation at $37^{\circ} \mathrm{C}$, and vented throughout via a fermentation lock.

Viable counts were determined in triplicate on bloodagar plates (Oxoid Blood Agar Base No. 2 supplemented with citrated or defibrinated sheep blood $5 \%$ ) and incubated 5-7 days at $37^{\circ} \mathrm{C}$ under $\mathrm{N}_{2}$ with $\mathrm{CO}_{2} 10 \%$. Optical densities of cultures at $450 \mathrm{~nm}$ were determined on a Pye Unicam SP6-550 spectrophotometer with $1-\mathrm{cm}$ cuvettes. Percentage motility was estimated by phasecontrast microscopy.

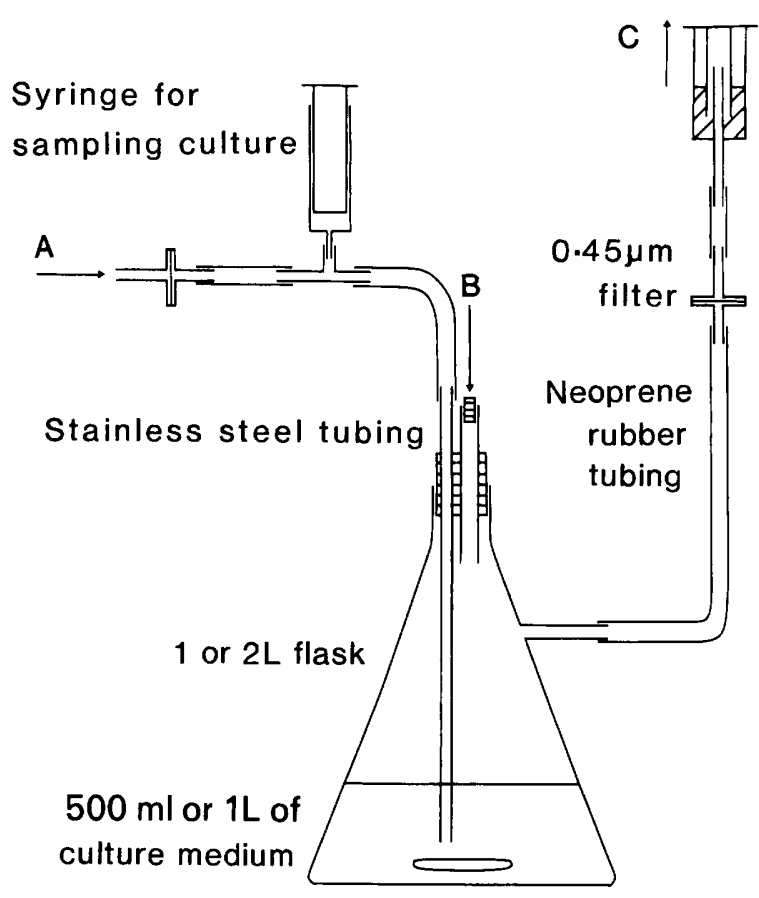

Stirring magnet

Fig. 1. Diagrammatic representation of the flask system used for culturing $T$. hyodysenteriae. During preparation, deoxygenated gas is pumped through the $0.45-\mu \mathrm{m}$ filter at $\mathrm{A}$. Throughout incubation the inlet is sealed. Serum, sodium bicarbonate and cysteine are injected at $\mathrm{B}$ when the temperature of the culture medium has dropped to $45-50^{\circ} \mathrm{C}$. The fermentation lock filled with water (C) allows the release of gaseous metabolites throughout the incubation period.

\section{Preparation of haemolysin}

$T$. hyodysenteriae was harvested from RSB by centrifugation at $15000 \mathrm{~g}$ for $30 \mathrm{~min}$ at $4^{\circ} \mathrm{C}$ and suspended in phosphate buffered saline (PBS) containing $1 \mathrm{~mm}$ glucose, $1 \mathrm{~mm}$ magnesium sulphate and RNA-core $0.05 \%$ (RNAcore buffer). The spirochaete suspension was incubated at $37^{\circ} \mathrm{C}$ in a water bath for $30 \mathrm{~min}$ and the organisms sedimented by centrifugation at $15000 \mathrm{~g}$ for $30 \mathrm{~min}$. The supernate containing the haemolysin was decanted, filtered through a $0.45-\mu \mathrm{m}$ membrane filter and titrated for haemolytic activity. The pellet of organisms was resuspended in fresh RNA-core buffer and the procedure was repeated three times.

\section{Titration of haemolytic activity}

Citrated sheep blood was washed three times and a $1 \%$ suspension of erythrocytes prepared in PBS. Two-fold dilutions of the sample under test were made in PBS and an equal volume of $1 \%$ erythrocyte suspension added. The test was incubated for $2 \mathrm{~h}$ at $37^{\circ} \mathrm{C}$ followed by $18 \mathrm{~h}$ 
at $4^{\circ} \mathrm{C}$. Haemoglobin release was measured at $545 \mathrm{~nm}$ wavelength. The endpoint of the titration was the highest dilution showing $50 \%$ haemolysis $\left(\mathrm{OD}_{545 \mathrm{~nm}}^{1 \mathrm{~cm}}=0.5\right)$. One haemolytic unit ( $1 \mathrm{HU})$ was defined as the amount of haemolysin required to lyse $50 \%$ of a $1 \%$ erythrocyte suspension.

\section{Concentration, desalting and storage of haemolysin}

Dialysis was performed with Visking and Cup size tubing with mol. wt cut-off values of $c .30000$ and 10000 respectively (Williams and Chase, 1968). Tubing was either soaked overnight in double distilled water (DDW) or $\mathrm{NaHCO}_{3} 5 \%$ or boiled in the latter solution for $5 \mathrm{~min}$ and washed thoroughly.

Concentration and desalting was performed at $4^{\circ} \mathrm{C}$ in a 60-ml ultrafiltration cell (Amicon Ltd, Stonehouse, Gloucester) with a YM 5 Diaflo ultrafiltration membrane (5000 mol. wt cut-off). Samples were concentrated to 1$2 \mathrm{ml}$ and washed repeatedly with DDW. Concentrated and desalted samples were stored at $-20^{\circ} \mathrm{C}$ either frozen or lyophilised. These preparations constituted the unpurified haemolysin and were the starting material for purification.

\section{Purification}

Chromatography columns $(1.6 \times 30 \mathrm{~cm}$ or $2 \times 30 \mathrm{~cm})$ were prepared at $4^{\circ} \mathrm{C}$ with Sephadex G100, DEAE cellulose or hydroxylapatite (Bio-gel HTP). Sephadex G100 was eluted with PBS containing $1 \mathrm{mM}$ glucose and $1 \mathrm{mM} \mathrm{MgSO}$, DEAE cellulose with PBS followed by a linear gradient of $0-0.4 \mathrm{M} \mathrm{NaCl}$ in PBS, and hydroxylapatite with a linear gradient of $0-0.5 \mathrm{M}$ potassium phosphate (equal volumes of $\mathrm{K}_{2} \mathrm{HPO}_{4}$ and $\mathrm{KH}_{2} \mathrm{PO}_{4}$ ) in PBS; 1-, 2or 5-ml fractions were collected and assayed for haemolytic activity, RNA $\left(\mathrm{OD}_{260 \mathrm{~mm}}^{1 \mathrm{~cm}}\right)$, protein, and RNAase activity. Fractions with haemolytic activity were pooled, desalted by ultrafiltration and lyophilised. The specific activity was defined as the haemolytic activity/mg of protein and the purification factor calculated by dividing the specific activity of the purified material by that of the unpurified material.

\section{Estimation of protein and detection of RNAase activity}

Protein was estimated by the Bio-Rad Protein Assay (Bio-Rad Laboratories Ltd, Watford, Herts) with ovalbumin as a standard. For detection of RNAase activity, $10-\mu \mathrm{l}$ volumes of fractions under test were spotted on to dried plates of Difco Noble Agar $1.5 \%$ containing NaRNA $5 \mu \mathrm{g} / \mathrm{ml}$ and incubated for $2 \mathrm{~h}$ at $37^{\circ} \mathrm{C}$. RNAase $(1 \mathrm{mg} / \mathrm{ml}$ ) from bovine pancreas was used as a positive control. Zones of clearing were detected by flooding the plates with $1.0 \mathrm{M} \mathrm{HCl}$.

\section{Polyacrylamide gel electrophoresis}

Sodium dodecyl sulphate-polyacrylamide gel electrophoresis (SDS-PAGE) was performed with the discontinuous buffer system of Laemmli (1970). Vertical slab gels were prepared with a $12 \% \mathrm{w} / \mathrm{v}$ running gel and a $3.75 \%$ $\mathrm{w} / \mathrm{v}$ stacking gel. Samples for electrophoresis were dissociated by boiling in $62.5 \mathrm{~mm}$ Tris- $\mathrm{HCl}$, SDS $2 \%$ $\mathrm{w} / \mathrm{v}, 2$-mercaptoethanol $2 \% \mathrm{v} / \mathrm{v}$ and glycerol $1 \% \mathrm{v} / \mathrm{v}$. The gels were run at a constant voltage of $150 \mathrm{~V}$ for $3-5 \mathrm{~h}$. Gels were stained either with Coomassie brilliant blue or by a silver stain based on the method described by Merril et al. (1981).

Native protein samples were electrophoresed in a nondissociating continuous electrophoresis system similar to that described by Hames (1981). Gels consisted of acrylamide (37.5:1 acrylamide: bisacrylamide) $12 \% \mathrm{w} / \mathrm{v}$ and $0.375 \mathrm{M}$ Tris $\mathrm{HCl}$ at $\mathrm{pH} 8.8$ and were polymerised with TEMED $0.025 \% \mathrm{v} / \mathrm{v}$ and riboflavin $0.0005 \% \mathrm{w} / \mathrm{v}$. The reservoir buffer consisted of $0.025 \mathrm{M}$ Tris and $0.192 \mathrm{M}$ glycine at $\mathrm{pH} \mathrm{8 \cdot 3.} \mathrm{Gels} \mathrm{were} \mathrm{electrophoresed} \mathrm{for} 45 \mathrm{~min}$ at $150 \mathrm{~V}$ before samples were loaded. Electrophoresis was then continued for a further $90 \mathrm{~min}$. Gels were either stained with silver or laid on to Oxoid Blood Agar No. 2 agar base containing washed sheep erythrocytes $5 \%$. Blood-agar overlays were incubated at $37^{\circ} \mathrm{C}$ for $24 \mathrm{~h}$ or until zones of haemolysis appeared.

\section{Molecular weight determination}

The mol. wt of the haemolysin was determined by gel filtration on a $2 \times 75 \mathrm{~cm}$ Sephadex G50 column previously equilibrated with PBS (Andrews, 1964). A sample of purified haemolysin was loaded together with a mixture of six protein standards of known mol. wt: Blue dextran 2000 , albumin (66000), ovalbumin (45000), chymotrypsinogen (25000), soybean trypsin inhibitor (21 500), and myoglobin $(17000)$ from Sigma. The elution profile of standard markers was assessed by SDS-PAGE and the BioRad protein assay. The mol. wt of the haemolysin was estimated by comparison of the elution pattern of the sample with that of the standards.

\section{Results}

\section{Culture of T. hyodysenteriae}

The optimum time for harvesting spirochaetes for production of haemolysin was determined with bottle cultures. As shown in fig. 2, the highest concentration of haemolysin was obtained after incubation for $46 \mathrm{~h}$, when the viable count was at its peak but before the highest optical density was reached at $70 \mathrm{~h}$. After $46 \mathrm{~h}, 80-100 \%$ of the spirochaetes were actively motile, whereas after $70 \mathrm{~h}$, when the culture was in the stationary phase, only $20-30 \%$ of the spirochaetes were sluggishly motile. 


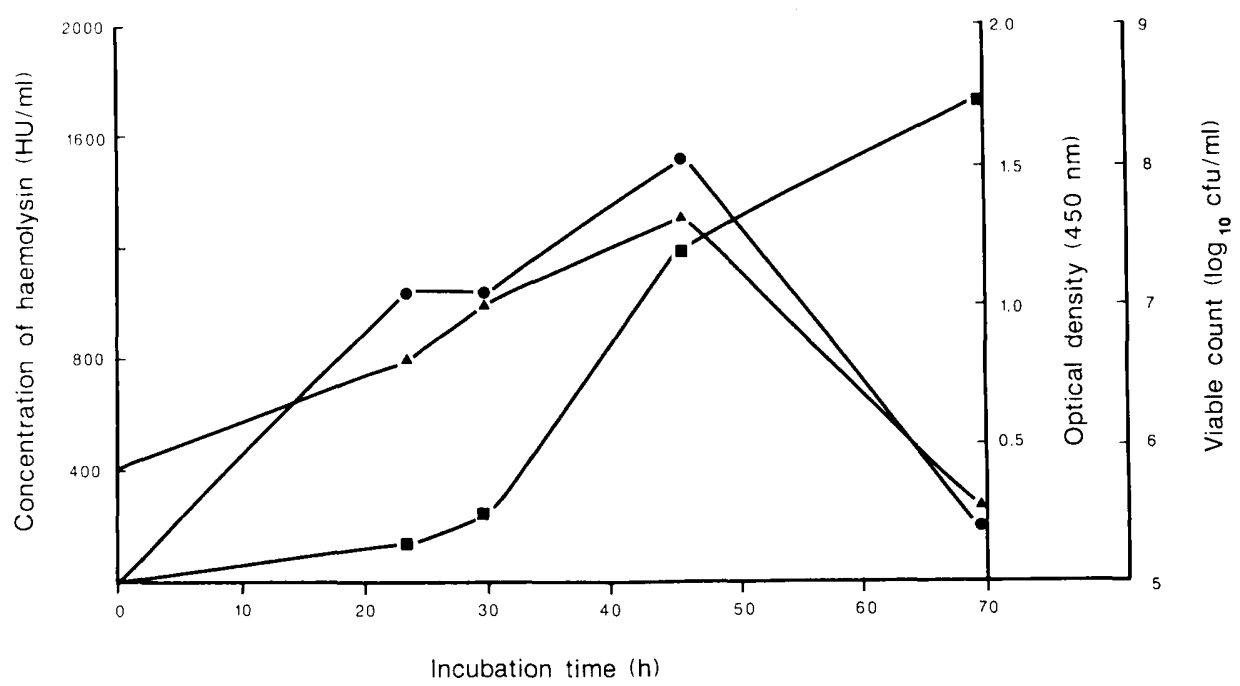

Fig. 2. Production of haemolysin from $T$. hyodysenteriae strain P18A harvested after different periods of incubation of the culture. The concentration of haemolysin $(\bullet-\bullet)$ was the yield obtained by resuspending the harvested organisms to a standard opacity in RNA-core buffer. Suspensions were incubated for $30 \mathrm{~min}$ at $37^{\circ} \mathrm{C}$ and haemolysin was obtained in the supernate. When organisms were harvested, the viable count $(\boldsymbol{\Delta}-\mathbf{\Delta})$ was estimated on blood-agar plates and the total count $(\boldsymbol{\square}-\mathbf{\square})$ determined by measuring the optical density at $450 \mathrm{~nm}$. $\mathrm{HU}=$ haemolytic units.

A comparison was made of the amount of haemolysin produced by spirochaetes from bottle cultures and flask culture, both harvested when 90 $100 \%$ of the spirochaetes were actively motile. The growth rate of spirochaetes cultured in flasks was greater than that in bottles, therefore flask cultures were harvested at $20 \mathrm{~h}$. The results are shown in table I. The viable count of the flask culture was 50 -fold greater than that of the bottle cultures. The total yield of haemolysin/L from spirochaetes grown in the flask was 9-fold greater than that obtained from bottle cultures.

\section{Production of haemolysin in RNA-core buffer}

Concentration of spirochaetes. Spirochaete suspensions with $\mathrm{OD}_{500 \mathrm{~nm}}^{1} \mathrm{~cm}$ of $0 \cdot 4,0 \cdot 6,0 \cdot 8,1 \cdot 0,1 \cdot 2$ and $1 \cdot 4$ when diluted ten-fold produced concentrations of haemolysin between 512 and $4096 \mathrm{HU} / \mathrm{ml}$. Since the yield was $2048 \mathrm{HU} / \mathrm{ml}$ from suspensions corre-

Table I. Comparison of two methods of culturing T. hyodysenteriae strain P18A for haemolysin production

\begin{tabular}{|c|c|c|c|c|c|}
\hline \multirow{2}{*}{$\begin{array}{l}\text { Method of culture } \\
\text { (inoculum size; incu- } \\
\text { bation time) }\end{array}$} & \multirow{2}{*}{$\begin{array}{l}\text { Viable count } \\
\quad(\mathrm{cfu} / \mathrm{ml})\end{array}$} & \multicolumn{3}{|c|}{$\begin{array}{l}\text { Titre of haemolysin prep- } \\
\text { arations }(\mathrm{HU} / \mathrm{ml})\end{array}$} & \multirow{2}{*}{$\begin{array}{l}\text { Total yield of haemolysin/L } \\
\text { of culture } \\
(\mathrm{HU} / \mathrm{ml})\end{array}$} \\
\hline & & $\mathrm{Hl}$ & $\mathrm{H} 2$ & $\mathrm{H} 3$ & \\
\hline $\begin{array}{l}\text { Bottles } \\
(1 \% ; 46 \mathrm{~h})\end{array}$ & $1 \cdot 1 \times 10^{7}$ & 2048 & 2048 & 1024 & $2.73 \times 10^{5}$ \\
\hline $\begin{array}{l}\text { Flask } \\
(10 \% ; 20 \mathrm{~h})\end{array}$ & $6.0 \times 10^{8}$ & 10240 & 2560 & 1280 & $2.47 \times 10^{6}$ \\
\hline
\end{tabular}

$\mathrm{H} 1, \mathrm{H} 2$ and $\mathrm{H} 3$ are the haemolysin yields from the first, second and third incubations, respectively, of spirochaetes suspended in RNA-core buffer. Bottle cultures consisted of 50-ml volumes of RSB in 20-oz bottles. Flask cultures were $1-\mathrm{L}$ volumes of RSB in 2-L side-arm conical flasks. The yield from $1 \mathrm{~L}$ of bottle-grown culture is an estimate calculated from the amount obtained from $100 \mathrm{ml}$ of culture.

$\mathrm{HU}=$ Haemolytic units. 
sponding to $\mathrm{OD}_{500 \mathrm{~nm}}^{1 \mathrm{~cm}}$ values of $0 \cdot 8,1 \cdot 0$ and $1 \cdot 2$, and higher concentrations of spirochaetes resulted in only a 2-fold increase, the standard concentration chosen was that giving an $\mathrm{OD}_{500 \mathrm{~nm}}$ of 1.0 at a tenfold dilution.

pH of the buffer. Spirochaetes suspended to the standard opacity in RNA-core buffer adjusted with $1.0 \mathrm{M} \mathrm{HCl}$ or $1.0 \mathrm{M} \mathrm{NaOH}$ to five different $\mathrm{pH}$ values in the range $5 \cdot 5-7 \cdot 5$ all yielded $4096 \mathrm{HU} / \mathrm{ml}$, the same as that obtained in the unadjusted buffer at $\mathrm{pH} 6 \cdot 2$.

Duration of incubation at $37^{\circ} \mathrm{C}$. Maximum haemolysin concentrations of $4096 \mathrm{HU} / \mathrm{ml}$ were produced after incubation for $30 \mathrm{~min}, 1 \mathrm{~h}$ and $2 \mathrm{~h}$ at $37^{\circ} \mathrm{C}$ from spirochaete suspensions at the standard opacity. After incubation for $4 \mathrm{~h}$ the concentration of haemolysin was $2048 \mathrm{HU} / \mathrm{ml}$. Thus, there was no advantage in extending the incubation period beyond $30 \mathrm{~min}$.

Repeated production of haemolysin. Suspension and incubation of the same spirochaetes four times in RNA-core buffer for 30 min produced haemolysin concentrations of 2048, 2048, 1024 and $512 \mathrm{HU} /$ $\mathrm{ml}$ demonstrating that it was possible to produce several batches of haemolysin from the same spirochaetes.

\section{Desalting and concentration of haemolysin}

Dialysis of haemolysin for $24 \mathrm{~h}$ at $4^{\circ} \mathrm{C}$ against DDW or PBS, with one change of dialysis fluid, resulted in an 8-20-fold decrease in activity when
DDW was used and a 2-fold decrease with PBS, irrespective of the method of pretreatment of the dialysis tubing. Haemolysin held at $4^{\circ} \mathrm{C}$ for the same period showed only a 2 -fold reduction in titre.

Three Diaflo ultrafiltration membranes were compared for their ability to retain haemolysin above the filter. A YM5 filter with a pore size of $5000 \mathrm{~mol}$. wt retained $99.9 \%$ of the activity and a PM10 filter with a pore size of $10000 \mathrm{~mol}$. wt retained $97.5 \%$, whereas the PM30 filter with a 30000 mol. wt pore size retained only $60 \%$.

\section{Purification of haemolysin}

Passage of unpurified haemolysin through Sephadex G100 or hydroxylapatite failed to separate haemolytic activity adequately from contaminating RNA, protein and also RNAase, which was shown to be present in the RNA-core. However, DEAE cellulose separated the haemolysin from RNAase activity and all extraneous protein, but not completely from unbound RNA (fig. 3).

The purification achieved by a combination of DEAE cellulose and Sephadex G100 chromatography is summarised in table II. Passage of haemolysin through DEAE cellulose gave a high recovery of haemolytic activity $(70-80 \%)$ with a purification factor of 11 . A subsequent passage through Sephadex G100 increased the specific activity and the purification factor of the haemolysin recovered. However, the yield was decreased. A second passage through Sephadex G100 pro-

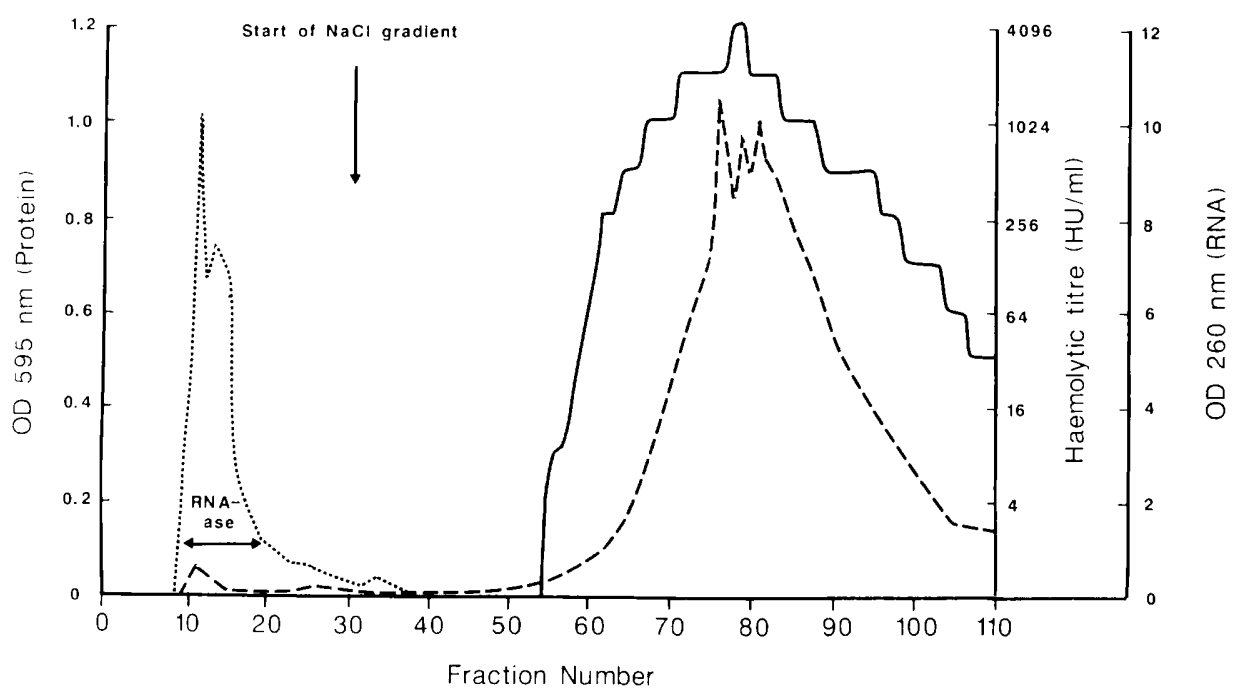

Fig. 3. Elution profile of haemolysin produced by $T$. hyodysenteriae strain P18A fractionated on Whatman DEAE cellulose. The column was packed and equilibrated with PBS at $4^{\circ} \mathrm{C}$. The sample was eluted with $60 \mathrm{ml}$ of PBS followed by a linear gradient of $0-$ $0.4 \mathrm{M} \mathrm{NaCl}$ in PBS starting at fraction 30;2-ml fractions were collected and assayed for haemolytic activity $(-\longrightarrow)$, RNA (- -), protein $(\cdots \cdots)$ and RNAase activity. 
Table II. Assessment of purification of treponemal haemolysin achieved by different chromatographic methods

\begin{tabular}{lccc}
\hline $\begin{array}{l}\text { Purification } \\
\text { method }\end{array}$ & $\begin{array}{c}\text { Total } \\
\text { recovery }\end{array}$ & $\begin{array}{c}\text { Specific activ- } \\
\text { ity (HU/mg } \\
\text { of protein) }\end{array}$ & $\begin{array}{c}\text { Purification } \\
\text { factor* }\end{array}$ \\
\hline Unpurified & - & $6.86 \times 10^{4}$ & - \\
DEAE Cellulose $\dagger$ & $70 \%$ & $7.75 \times 10^{5}$ & 11 \\
DEAE + G100 & $48 \%$ & $1.93 \times 10^{6}$ & 28 \\
DEAE $+2 \times$ G100 & $29 \%$ & $3.11 \times 10^{6}$ & 45
\end{tabular}

$*$ Purification factor $=\frac{\text { specific activity of purified material }}{\text { specific activity of unpurified material }}$. † A $2 \times 30 \mathrm{~cm}$ Whatman DEAE cellulose column was eluted with a linear gradient of $0-0.4 \mathrm{M} \mathrm{NaCl}$ in PBS.

$\ddagger$ A $1.6 \times 30 \mathrm{~cm}$ Sephadex G100 column was eluted with PBS containing $1 \mathrm{~mm}$ glucose and $1 \mathrm{~mm} \mathrm{MgSO}$.

Fractions showing haemolytic activity were pooled, desalted or concentrated, or both, and lyophilised.

duced a further increase in specific activity and purification factor but a further decrease in yield.

When purity was assessed by SDS-PAGE stained with CBB or silver, unpurified haemolysin gave several bands, one of $66000 \mathrm{~mol}$. wt being particu- larly prominent (fig. 4 a, track 1). A single band, which migrated just ahead of the tracking dye and stained poorly with CBB but well with silver, originated from the RNA-core (fig. $4 a$, tracks 1 and 2). After passage through DEAE cellulose or DEAE cellulose and Sephadex G100, only this fast moving band ahead of the tracking dye was detectable if gels were stained with the sensitive silver stain. When the partially purified material was concentrated 100 -fold, up to 10 bands migrating in a position with or ahead of the tracking dye were seen and no bands were present in the upper part of the gel (fig. $4 \mathrm{~b}$, track 1). When the RNA-core carrier was purified and concentrated in an identical manner, a similar number of bands was observed running in the same position (fig. 4b, track 2).

When haemolysin or the RNA-core carrier (purified on DEAE cellulose and concentrated) was run on a non-dissociating gel, up to 10 bands were again resolved (fig. 5a). All bands migrated well into the gel within $90 \mathrm{~min}$. By overlaying the polyacrylamide gel with blood agar, only one of the slowest moving bands of the haemolysin preparation was shown to have haemolytic activity (fig. 5b). This band was present in the haemolysin preparation and also in the RNA-core carrier although the carrier alone did not show haemolytic activity.

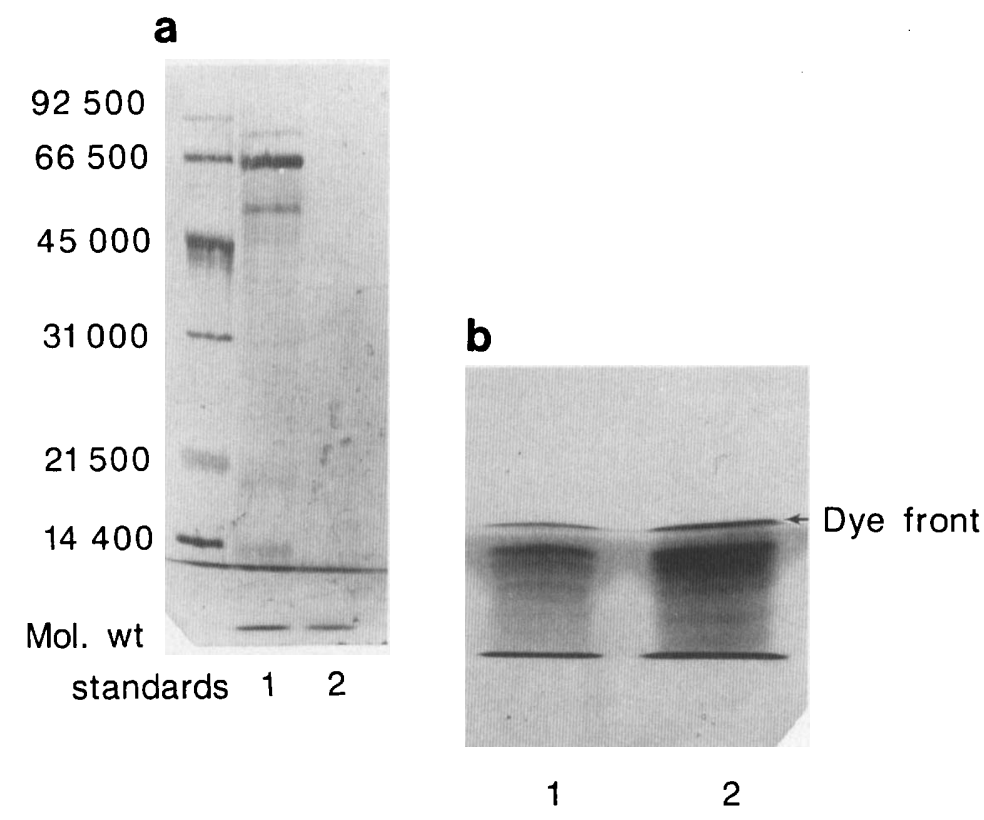

Fig. 4. Analysis of haemolysin by SDS-PAGE. a. Silver stain of unpurified haemolysin (track 1) and the RNA-core carrier (track 2). b. Silver strain of haemolysin partially purified on DEAE cellulose (track 1) and the RNA-core carrier alone (track 2) purified in an identical manner. Samples (b) 1 and 2 were pools of fractions 60-70 (see fig. 3), concentrated by ultrafiltration to $1 \mathrm{ml}$. Gels were prepared with a $3 \cdot 75 \%$ stacking gel and a $12 \%$ running gel. Samples were electrophoresed at a constant voltage of $150 \mathrm{~V}$ for 3-4 h. 


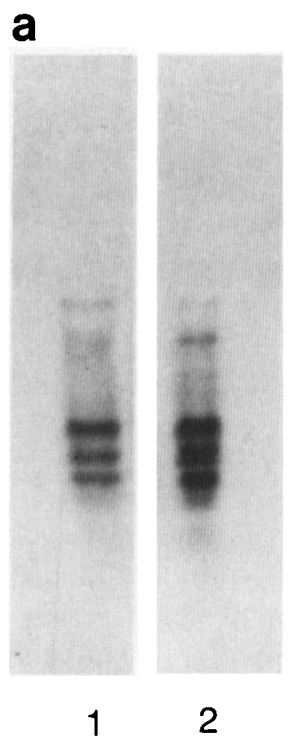

b

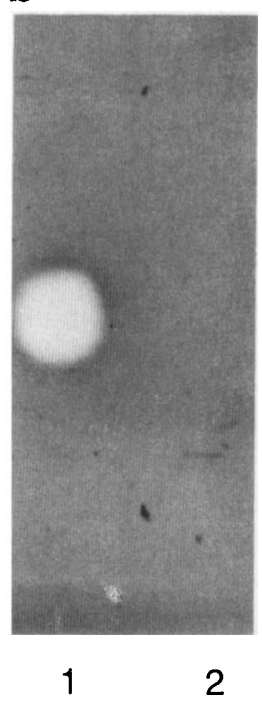

Fig. 5. Analysis of RNA-haemolysin by non-dissociating PAGE. a. Silver stain of haemolysin (track 1) and RNA-core (track 2) purified on Whatman DEAE cellulose. b. Blood-agar overlay of a showing a zone of haemolysis over the track containing haemolysin (track 1) but none over the track containing RNAcore (track 2). The haemolytic zone aligns with a band present in both haemolysin preparations and the RNA-core. Samples were separated on a continuous, non-dissociating $12 \%$ polyacrylamide gel. Gels were pre-electrophoresed at $150 \mathrm{~V}$ constant voltage for $45 \mathrm{~min}$. After sample application, electrophoresis was continued for a further $90 \mathrm{~min}$.

\section{Mol. wt determination by gel filtration}

The elution profile of partially purified haemolysin from Sephadex G50 is shown in fig. 6, together with that of the protein standards. By plotting the elution volume against the mol. wts of the standards, the mol. wt of the purified haemolysin was estimated to be 19000 .

\section{Discussion}

The methods described for preparation and purification of haemolysin from spirochaetes in suspension produced greater yields of more highly purified material than had been reported previously. Specific activities of up to $4 \times 10^{6} \mathrm{HU} / \mathrm{mg}$ of protein were obtained compared with values of $5 \times 10^{3} \mathrm{HU} /$ $\mathrm{mg}$ and $8.9 \times 10^{4} \mathrm{HU} / \mathrm{mg}$ reported by Saheb et al. (1980) and Knoop (1981) respectively.

Increased recovery was possible because a high concentration of up to $10000 \mathrm{HU} / \mathrm{ml}$ of unpurified haemolysin was available as the starting material for purification whereas Saheb et al. (1980) and Knoop (1981) only had crude haemolysin preparations at a titre of $1000 \mathrm{HU} / \mathrm{ml}$. This higher yield resulted from the availability of large numbers of spirochaetes from flask cultures and the production of haemolysin in RNA-core buffer under optimum conditions. Another important factor was the ability to obtain several batches of haemolysin from

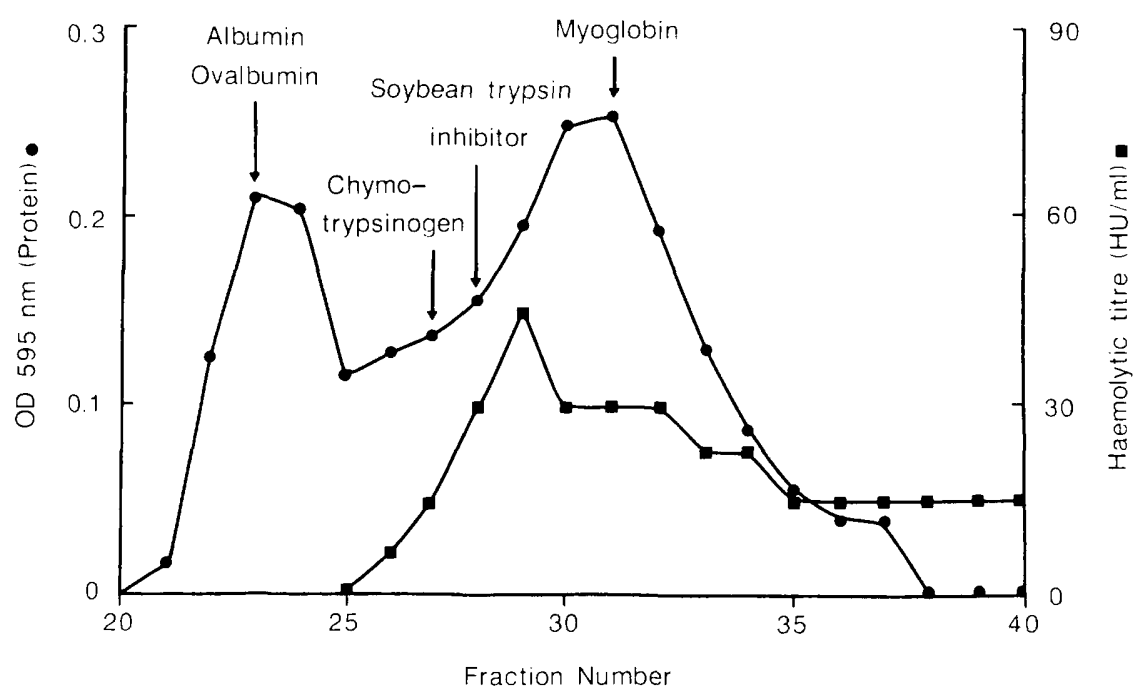

Fig. 6. Elution of protein standards and haemolysin from Sephadex G50. A $2 \times 75 \mathrm{~cm}$ column was equilibriated with PBS at $4{ }^{\circ} \mathrm{C}$. The mixture of haemolysin and protein standards was loaded and eluted with PBS; $2-\mathrm{ml}$ fractions were collected and assayed for protein $(\bullet-\bullet)$ and haemolytic activity ( 
the same spirochaetes by resuspending and reincubating them in fresh RNA-core buffer. This was known to be effective with streptococci (Bernheimer, 1949) but had not previously been described for $T$. hyodysenteriae.

The improved yield of spirochaetes from flasks compared with bottle cultures may be due in part to venting of the flasks. This allowed the escape of gases which were generated during the incubation of the cultures and which may have been toxic. The flask system had two additional advantages over bottle cultures. Firstly, spirochaetes were ready to harvest after incubation for about $20 \mathrm{~h}$, and secondly, a more uniform population of spirochaetes was obtained from a single flask containing $1 \mathrm{~L}$ of culture than from 20 bottles each containing $50 \mathrm{ml}$. By continuously stirring the flask cultures (Harris, 1980), it was found to be unnecessary to have the large gas-liquid interface required for growth in bottles and tubes (Lemcke et al., 1979). It is still unclear why such intimate association of the culture fluid with the gaseous phase is necessary for the growth of $T$. hyodysenteriae in liquid medium.

The starting material used for purification of the treponemal haemolysin was different from that used by earlier workers. Both Saheb et al. (1980) and Knoop (1981) used culture supernates harvested when the maximum amount of haemolysin was present. Saheb et al. (1980) found that this was at the end of the logarithmic phase whereas Knoop (1981) obtained highest yields after incubation for only $8 \mathrm{~h}$. In our study, spirochaetes were harvested when they could most actively produce haemolysin in RNA-core buffer; this occurred in the mid-tolate logarithmic phase when a very high percentage of the spirochaetes was actively motile. Ginsburg (1970) noted that for production of streptolysin S, streptococci must be metabolically active. $\mathrm{He}$ suggested that the production of streptolysin $\mathrm{S}$ in RNA-core buffer depends on an active metabolic process rather than the physical extraction of preformed intracellular haemolysin. The same is probably true of the treponemal haemolysin, since it was possible to go on producing haemolysin from the same spirochaetes by reincubating in fresh buffer. A further indication is the observation of Lemcke and Burrows (1982) that maximum haemolysin production occurred in RNA-core buffer at $37-42^{\circ} \mathrm{C}$, the temperature range optimal for growth of $T$. hyodysenteriae.

The haemolysin obtained in RNA-core buffer was desalted and concentrated by a rapid ultrafiltration system with very little loss of activity. The unpurified haemolysin thus provided a more con- centrated starting material for purification than that used by earlier workers. Moreover, since the haemolysin was produced in a simple defined buffer the initial step of ammonium sulphate precipitation used by Saheb et al. (1980) and Knoop (1981) in purifying haemolysin from culture supernates was unnecessary.

Ion-exchange chromatography on DEAE cellulose followed by gel filtration on Sephadex G100 gave the most pure preparation as assessed by silver staining of polyacrylamide gels. A combination of DEAE cellulose and Sephadex G100 was the method used by Saheb et al. (1980) and Knoop (1981). The results obtained with hydroxylapatite as the first stages of purification were disappointing, especially as it was used successfully by Loridan and Alouf (1984) for purification of streptolysin S.

The elution profile of the treponemal haemolysin from DEAE cellulose was remarkably similar to that of streptolysin S (Lai et al., 1978), although this may be a property of the RNA-core carrier rather than of the haemolysins (Ginsburg, 1970). Treponemal haemolysin started to elute from the DEAE cellulose column at a $\mathrm{NaCl}$ concentration of $0.3 \mathrm{M}$ with maximum elution at $0 \cdot 35 \mathrm{M}$. However, Knoop (1981) found that haemolysin was eluted at a concentration of about $0 \cdot 6 \mathrm{M}$. This discrepancy may be due to differences in the carriers involved, because haemolysin prepared from cultures supplemented with serum as well as RNA-core may be bound to other carriers besides RNA, e.g., serum albumin (Ginsburg, 1970).

The mol. wt of 19000 , calculated from the gel filtration results, is lower than the previous estimates of 74000 from gel filtration (Saheb et al., 1980) and 68000 from SDS-PAGE (Knoop, 1981). The value of 19000 is similar to the mol. wt estimates (11000 and 18000$)$ for streptolysin S (Bernheimer, 1967; Calandra and Oginsky, 1975; Lai et al., 1978). Hryniewicz et al. (1978) reported that the mol. wt of streptolysin $\mathrm{S}$ as determined by gel filtration was 11000,22000 and 40000 depending on the elution buffer used, and suggested that aggregates formed under different conditions. The high mol. wt of the treponemal haemolysin reported by Saheb et al. (1980) could be due to the use of a different elution buffer. Alternatively, the discrepancy in size may be due to the different methods of extraction and also the size of the carrier used.

Two other observations support the conclusion that the haemolysin of $T$. hyodysenteriae produced in RNA-core buffer had a low mol. wt. First, it was not possible to desalt the haemolysin by simple dialysis without considerable loss of activity. Moreover, retention was better when an ultrafiltration 
membrane with a $5000 \mathrm{~mol}$. wt cut-off was used than with those with a 10000 or 30000 cut-off. Secondly, the SDS-PAGE results on the most highly purified preparations of haemolysin showed only bands running with or just ahead of the tracking dye. Similarly, the fast migration through a nondissociating gel provides further evidence that the haemolysin molecule is small and highly charged. Analysis of the partially purified haemolysin by SDS-PAGE and non-dissociating PAGE revealed that no additional stained bands were present when compared with the carrier alone. However, the gel overlay technique demonstrated that one of the common bands was haemolytic in samples containing the haemolysin. This may suggest that the haemolysin is tightly bound to a component of the RNA-core from which it is not easily dissociated. It is noteworthy that although Saheb et al. (1980) obtained a mol. wt value for the haemolysin of 78000 by gel filtration, they reported that the haemolysin migrated very close to the tracking dye in SDS-PAGE and stained poorly with Coomassie

\section{REFERENCES}

Andrews P 1964 Estimation of the molecular weights of proteins by Sephadex gel-filtration. Biochemical Journal 91 :222-233.

Bernheimer A W 1949 Formation of a bacterial toxin (Streptolysin S) by resting cells. Journal of Experimental Medicine 90:373-392.

Bernheimer A W 1967 Physical behaviour of Streptolysin S. Journal of Bacteriology 93:2024-2025.

Bernheimer A W 1972 Haemolysins of streptococci: characterisation and effects on biological membranes. In: Wannamaker L W, Matsen J M (eds) Streptococci and Streptococcal diseases. Academic Press, New York, pp 1931.

Calandra G B, Oginsky E L 1975 Cellular streptolysin S-related hemolysins of Group A Streptococcus C203S. Infection and Immunity 12: 13-28.

Ginsburg I 1970 Streptolysin S. In: Montie T C et al. (eds) Microbial toxins, vol III. Academic Press, New York, pp $99-171$

Hames B D 1981 An introduction to polyacrylamide gel electrophoresis. In: Hames B D, Rickwood D (eds) Gel Electrophoresis of proteins: a practical approach. IRL Press, London, pp 1-91.

Harris D L 1980 Improved method for propagation of Treponema hyodysenteriae. In : Proceedings of the 6th International Pig Veterinary Society Congress, Copenhagen, p 244.

Harris D L, Glock R D, Christensen C R, Kinyon J M 1972 Swine dysentry. 1. Inoculation of pigs with Treponema hyodysenteriae (new species) and reproduction of the disease. Veterinary Medicine/Small Animal Clinician 67: 6164.

Hryniewicz W, Gray E D, Tagg J R, Wannamaker L W, Kanclerski K, Laible N 1978 Streptolysin S: purification and properties. Zentralblatt für Bakteriologie, Parasitenkunde, Infektionskrankheiten und Hygiene. 1. Abteilung Originale A 242: 327-338. brilliant blue although no attempt was made to demonstrate that this band had haemolytic activity. They suggested that this was due to association of the haemolysin with lipid and nucleotides, although enzymatic studies showed that the haemolysin was polypeptide in nature. In the light of these results it is possible that the single band with a mol. wt of 68000 observed by Knoop (1981) was a protein carrier and that the dissociated haemolysin was not detected because of its poor staining qualities.

The techniques described in this paper for producing large amounts of highly purified haemolysin from $T$. hyodysenteriae should facilitate further investigation of its possible role in the pathogenesis of swine dysentery.

The flask system for culturing $T$. hyodysenteriae though not previously published, was evolved jointly by Dr R. J. Lysons, Mrs J. Bew and Mr M. R. Burrows. We thank Dr R. Sellwood for this careful criticism of the manuscript. This work was supported by a grant from the Lister Institute of Preventive Medicine.

Hudson M J, Alexander T J L, Lysons R J, Wellstead P D 1974 Swine dysentery: failure of an attenuated strain of spirochaete, given orally, to protect pigs against subsequent challenge. British Veterinary Journal 130: xxxvii-xl.

Hudson M J, Alexander T J L, Lysons R J 1976 Diagnosis of swine dysentery: spirochaetes which may be confused with Treponema hyodysenteriae. Veterinary Record 99 : 498-500.

Kinyon J M, Harris D L 1979 Treponema innocens, a new species of intestinal bacteria and emended description of the type strain of Treponema hyodysenteriae Harris et al. International Journal of Systematic Bacteriology 29: 102-109.

Kinyon J M, Harris D L, Glock R D 1977 Enteropathogenicity of various isolates of Treponema hyodysenteriae. Infection and Immunity 15: 638-646.

Knoop F C 1981 Investigation of a hemolysin produced by enteropathogenic Treponema hyodysenteriae. Infection and Immunity 31: 193-198.

Laemmli U K 1970 Cleavage of structural proteins during the assembly of the head of bacteriophage T4. Nature 227:680685.

Lai C Y, Wang M-T, De Faria J B, Akao T 1978 Streptolysin S: improved purification and characterization. Archives of Biochemistry and Biophysics 191 : 804-812.

Lemcke R M, Bew J, Burrows M R, Lysons R J 1979 The growth of Treponema hyodysenteriae and other porcine intestinal spirochaetes in liquid medium. Research in Veterinary Science 26: 315-319.

Lemcke R L, Burrows M R 1982 Studies on a haemolysin produced by Treponema hyodysenteriae. Journal of Medical Microbiology 15 : 205-214.

Loridan C, Alouf J E 1984 Production and purification of streptolysin S. In: Alouf J E et al. (eds) Bacterial protein toxins. Academic Press, London, pp 249-250.

Merril C R, Goldman D, Sedman S A, Ebert M H 1981 Ultrasensitive stain for proteins on polyacrylamide gels shows regional variation in cerebrospinal fluid proteins. Science 211 : 1437-1438. 
Picard B, Massicote L, Saheb S A 1979 Effect of sodium ribonucleate on the growth and hemoytic activity of Treponema hyodysenteriae. Experientia 35: 484-486.

Saheb S A, Massicote L, Picard B 1980 Purification and characterization of Treponema hyodysenteriae haemolysin. Biochimie 62: 779-785.
Taylor D J, Alexander T J L 1971 The production of dysentery in swine by feeding cultures containing a spirochaete. British Veterinary Journal 127: lviii-lxi.

Williams C A, Chase M W (eds) 1968 Methods in immunology and immunochemistry, vol II. Academic Press, London, p 161. 